\title{
The Non-audit Business Impact on Audit Independence and Its Research
}

\author{
Zhao Yan \\ School of Economic and Management, North China Electric Power University of Beijing, Beijing, China \\ Email address: \\ 610890074@qq.com
}

\section{To cite this article:}

Zhao Yan. The Non-audit Business Impact on Audit Independence and Its Research. Journal of Finance and Accounting. Vol. 4, No. 2, 2016, pp. 52-57. doi: 10.11648/j.jfa.20160402.14

Received: March 25, 2016; Accepted: April 6, 2016; Published: April 14, 2016

\begin{abstract}
With the development of social economy, the traditional audit review business of accounting firms already can't adapt to the fierce competition, according to the repositioning strategy, the development of non-audit services is imperative, but inevitably in the process of providing non-audit services there are a lot of problems, which is worthy to think and research them. This essay based on the characteristics of non-audit services and the related knowledge of economics, analyzes its influence on audit independence from positive and negative two aspects; by collecting relevant data and using two binary logistic regression model finally we get the analysis of influence of non-auditing services to audit independence amount, non-audit services have no substantial impact on the independence of the audit conclusion and puts forward relevant suggestions.
\end{abstract}

Keywords: Keyword Non-audit Services, Keyword Independence of the Audit, Keyword Influence, Keyword Two Binary Logistic Regression Model

\section{Introduction}

In 2001, the Enron incident happened, as one of the five famous accounting firms An XinDa office provide to Enron Corp not only audit services but also consulting business for many years, the non-audit business income is far greater than the audit income, which led to the public criticism and the solution of the body. After Enron incident, the United States promulgated the "Sarbanes Oxley act", for the accounting firms to provide non-audit services and audit the company to maintain the independence of audit [1].

In China, with a sharp rise in the proportion of non-audit services, there are many incidents that accounting firms not only provide non-audit services but also provide audit services by charging high fee. At the same time, a large number of incidents that audit independence were affected by non-audit services happened. The public worried about audit independence is compromised and requested to prohibit the accounting firm to provide non-audit business. As a result, it's very necessary for us to confirm whether non-audit services undermine the independence of the audit, which is worthy to study.

\section{The Non-audit Business Impact on Audit Independence}

\subsection{The Characters of Non-audit Services and Audit Independence}

Non-audit business is relative to the audit service and it provides the accounting firm with a certain fee for a variety of services such as tax consulting, management consulting, legal advice, and even technical advice, etc. Audit independence is the soul of the audit, which is the essential feature of the audit, and it is the cornerstone of the survival and development of the audit profession. Independence audit is a state of mind, which is not affected by external pressure and the auditors couldn't have any special interests with principal businesses and individuals.

\subsection{The Interactive Relationship Between Non-audit Services and Audit Independence}

Non-audit services have an impact on audit independence, which is caused by the double attributes of the public and the enterprise and the information asymmetry in the 
principal-agent relationship. This paper explains the relationship between non-audit services and audit independence from the following three aspects.

\subsubsection{Explanation of Public Economics}

An empirical study on the influence of non audit services on audit independence [J], 2007Modern market economy is composed of private economy and public economy, which is mixed economy. As a part of them, registered accountants industry has the nature of the social services and independent industry, through the audit, audit report out. Due to the special nature of the CPA profession, the audit report has the dual attributes of both public goods and private goods. At the same time, the public is also reflected in the audit business. If the audit opinions issued by the certified public accountants are not true or fair, they will affect the judgment of the public on the company, harm the interests of the public, and even disrupt the economic order of the society. Therefore, the CPA must fulfill its social responsibility, so as to realize the goal of the society, so it has the character of public goods. Audit products also have the nature of private products, this is because they are the main product of the CPA profession and the main source of the CPA industry. Accounting firms also need to consider the cost efficiency and achieve their own survival and development through the profit, which has the nature of the enterprise.

The CPA profession both the dual attributes of social services and independent industry, making it should achieve the goal of social responsibility in the process, which determines the CPA audit services is as a main function in the provision of services and non-audit services as a supplement.

\subsubsection{The Explanation Based on the Theory of Principal Agent}

In the Modern Corporation, the fundamental characteristics of corporate governance structure are the separation of ownership and management. The separation of two rights makes the operator become the firm's decision makers, which improve the efficiency of enterprise management and produced the "agency cost". Because the owner pursuit the maximization of enterprise value, and the operators pursuit individual utility maximization. So the two different aims produce the issue of "agency cost".

In addition, due to the information asymmetry between the principal and the agent, the principal may misunderstand the behavior of the agent. Therefore we need independent of both the third party audit coordination conflicts of interest between the party, the agent and commission, and thus effectively attestation, restraint and incentive to the agent and to promote the maximization of interests of both balanced, CPA fits well with the requirements for the third party [2].

However, non-audit services broke the original balanced state among client agent, certified public and accountants. The client agent and accountants which originally have no interests relation become two parties of the interests, making the original independent third party to the principal and the agent become into a double agent who ( as the Figure 1). Therefore, certified public accountant (CPA) which is the original one-way commission become multiple principal and register accountants and managers into stakeholders, resulting in a conspiracy of possibility and harming the principal interests of people (owner).

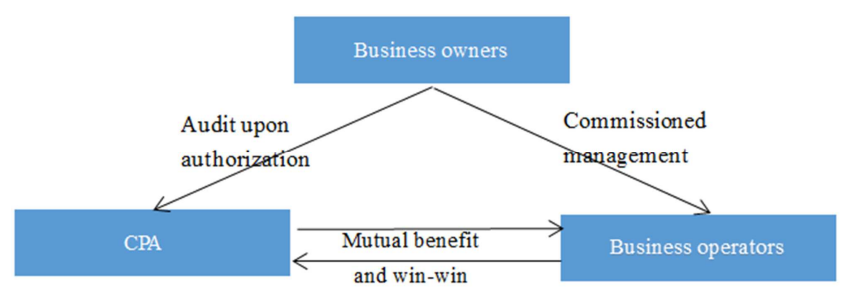

Figure 1. The relationship between the Audit Commission and the purchase of non audit business services.

\subsubsection{Explanation of Pareto's Efficiency}

Non-audit services is the inevitable outcome of the development of the times, in a certain extent consistent with Pareto improvement, Pareto improvement is that nobody got worse, but some people get better [3], and if non-audit services could carry out appropriately, achieving both help accountants firm profitability, and improve enterprise depending on their own, and help enterprises to achieve more truly and fairly reflect its financial situation this win-win situation. Under the function of the market, the rational and effective allocation of resources through independent and voluntary forms could achieve Pareto improvement and improve the efficiency of. However, if the implementation of non-audit business is not appropriate, it will have the opposite effect. As shown in the figure, the non-audit business in the ideal case, the efficiency can be moved from $\mathrm{D}$ point to point $\mathrm{P} 1$, to achieve the audit business MRS=MRT (Marginal rate of substitution $=$ marginal rate of conversion). However, if in the case of non-ideal, it is possible to achieve a negative Pareto efficiency, so that the efficiency of $\mathrm{P} 1$ points to move to the point of $\mathrm{D}$, resulting in waste of resources and inefficiency.

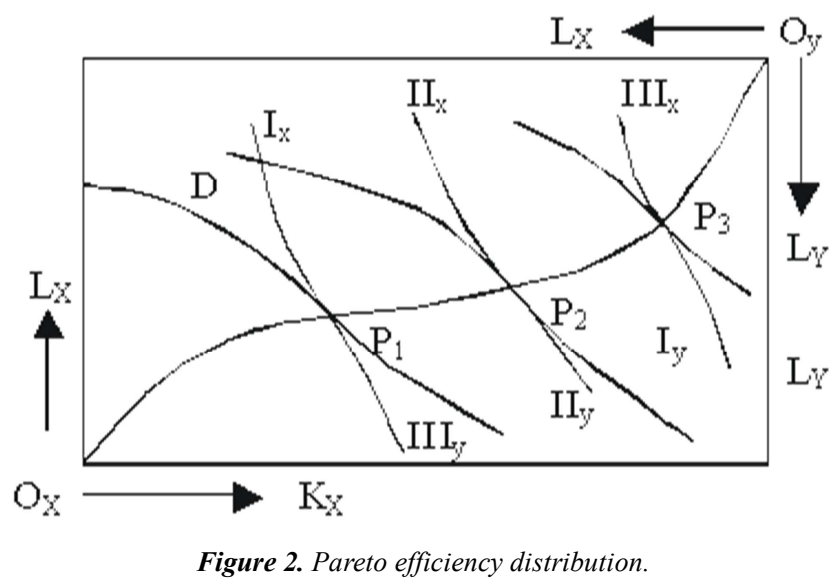




\section{The Influence of Non-audit Business on Audit Independence}

\subsection{Positive Influence}

\subsubsection{Synergistic Effect}

According to the theory of knowledge spillover effect, by providing non-audit services the CPA could further contact and understand the customer enterprise production operation and management of the situation, which to some extent will strengthen the audit effectiveness and reduce the audit risk. Certified public accountants provide non-audit services and obtain knowledge, which may be transferred to the audit service overflow, and thereby reducing the cost of audit services and improving audit efficiency. At the same time, audit services can make CPA correctly evaluate the client's internal control system, financial accounting system and the condition of corporate governance, in order to provide customers with a more focused, more effective non audit services.

\subsubsection{Aggregation Effect}

Aggregation effect makes professional knowledge accumulation and development.

The development of non-audit services is conducive for accounting firms to attract and retain experts in various types of enterprise management; accounting firms provide audit services and non-audit services, making full use of the accounting firm experts, reducing the external experts rely, enriching the accounting firm expert knowledge and skills, and helping accounting firms to develop and use of reasonable quality control policies and procedures.

\subsubsection{Dominant Position}

Non-audit business enterprise management consulting can make the certified public accountants in a more favorable position in the conflict and coordination with customers. Goldman and Barlev (1974) pointed out that the accounting firm provide for enterprise customers more non routine service, there will be stronger customer dependence of CPA. The CPA will be able to grasp more initiative in the interests of both sides of the conflict and coordination. Therefore, the development of non-audit services to a certain extent could enhance the status of certified public accountants and maintain its independence.

\subsection{Negative Influence}

\subsubsection{Conflict of Interest}

Nowadays, the audit service is competing viciously, which leads to the low income of audit services, forcing the accounting firms to seek new growth points. If non-audit services may get too high income, leading to the accounting firm for the customer the economic strong dependence. If the CPA disagrees with the customers, considering their own interests, in order to seize the opportunity and get more revenue it probably compromises that the issue of the customer needs of the unreasonable audit opinions.

\subsubsection{Role Conflict}

The public believes the qualification of Certified Public Accountants and has a high degree of recognition of the audit report issued by the public. Due to the non-audit business involves a large number of enterprise management, registered accountants to the corporate management advisory capacity may make public remain sceptical with the independence of Certified Public Accountants, even CPA indeed maintain a substantial independence, but public awareness is registered accounting division in favour of customers for the company and the effectiveness of audit report will be significantly reduced.

Based on the above theory, this paper puts forward the hypothesis: the non-audit business in China has no substantial impact on audit independence.

\section{The Hypothesis of Non-audit Business to Audit Independence}

\subsection{The Hypothesis of Research}

According to the above of non-audit services' influence on audit independence research review and summary of the previous research, the author puts forward the research hypothesis is: China's non-audit services to audit independence have no substantive impact.

\subsection{Sample Selection and Data Sources}

The sample involve listed companies annual financial data and firm ranking data is from in China's government supervisor, including official website of China registered accountant association website and the huge influx of information network announced 2012 to 2014, the annual report information by family sorted access, according to disclose the accounting firm audit of listed companies audit information, to obtain a total data of 176 listed companies. And classify the 176 listing Corporation by the industry. In addition, the process of statistical analysis in this paper uses Excel Microsoft and SPSS12.0 software.

\subsection{Model Building}

$$
\begin{aligned}
\ln \frac{p}{1-p}= & \beta_{0}+\beta_{1} \text { totalfee }+\beta_{2} \text { feeratio }+\beta_{3} \ln \text { asset }+\beta_{4} \mathrm{dta}+\beta_{5} \text { currat } \\
& +\beta_{6} \text { roe }+\beta_{7} \text { naps }+\beta_{8} \text { croe }+\beta_{9} \text { inventory }+\beta_{10} \text { receivable } \\
& +\beta_{11} \text { current }+\beta_{12} \text { asize }+\beta_{13} \text { tenture }+\mathcal{E}
\end{aligned}
$$




\subsection{Index Selection}

Table 1. Model index meaning and value.

\begin{tabular}{|c|c|c|c|c|}
\hline $\begin{array}{l}\text { Variable } \\
\text { representation }\end{array}$ & Variable name & Variable type & $\begin{array}{l}\text { Anticipation } \\
\text { symbol }\end{array}$ & value \\
\hline Opinion & audit opinion & dependent variable & & Non-standard audit opinion is 1 , otherwise 0 \\
\hline Totalfee & The total amount of audit fees & & - & Natural logarithm of the sum of audit fees \\
\hline Feeratio & Non audit fee & independent variable & - & Non-financial audit fees/total fee \\
\hline Lnasset & Company assets scale & & - & lnsize \\
\hline Dta & Asset liability ratio & & + & Liabilities / assets \\
\hline Currat & Flow rate & & - & Current assets / current liabilities \\
\hline Naps & Net asset value per share & & - & Net assets / shares \\
\hline Croe & Main business profit margin & & - & $\begin{array}{l}\text { Main business net profit / main business } \\
\text { income }\end{array}$ \\
\hline Inventory & $\begin{array}{l}\text { The proportion of inventory in total } \\
\text { assets at the end of the period }\end{array}$ & control variable & - & Ending inventory / total assets \\
\hline Receivable & $\begin{array}{l}\text { Final accounts receivable account for } \\
\text { total assets ratio }\end{array}$ & & - & Final accounts receivable / final total assets \\
\hline Current & tradable & & - & $\begin{array}{l}\text { Unlimited number of shares outstanding / the } \\
\text { total number of shares. }\end{array}$ \\
\hline Asize & Firm size & & + & The top ten of the year was 1 , otherwise 0 \\
\hline Tenure & Ftenure & & - & For several years the accountant \\
\hline
\end{tabular}

\section{Empirical Analysis}

\subsection{Descriptive Statistics on the Types of Audit Reports}

Table 2. Accounting firm size and audit opinion type description.

\begin{tabular}{llll}
\hline Variable name & Standard audit opinion & Non-standard audit opinion \\
\hline Large-scale accounting firm & 34 & 0 & total \\
Non - scale accounting firm & 133 & 9 & 9 \\
total & 167 & 9 & 176 \\
\hline
\end{tabular}

Source: China Institute of Certified Public Accountants

Through the above statistics, we can clearly see that the size of the two groups of accounting firms and the characteristics of the listing Corporation in the standard audit opinion group and the non-standard audit opinion group has a greater difference.

Analysing the characteristics of listed companies' effect on the type of audit report opinion in descriptive statistics is to through the statistics to discover that received standard opinion and non-opinion of listed companies financial indicators are different.

Table 3. Descriptive statistics on the impact of the characteristics of listing Corporation on the types of audit reports. [4]

\begin{tabular}{|c|c|c|c|c|c|c|}
\hline $\begin{array}{l}\text { Report opinion } \\
\text { type }\end{array}$ & variable & $\mathbf{N}$ & $\begin{array}{l}\text { Maximum } \\
\text { value }\end{array}$ & $\begin{array}{l}\text { minimum } \\
\text { value }\end{array}$ & $\begin{array}{l}\text { mean } \\
\text { value }\end{array}$ & $\begin{array}{l}\text { standard } \\
\text { deviation }\end{array}$ \\
\hline \multirow{9}{*}{$\begin{array}{l}\text { Auditing } \\
\text { standards }\end{array}$} & Asset size & 167 & 23.62 & 18.69 & 21.46 & 0.905 \\
\hline & Asset liability ratio (\%) & 167 & 917.25 & 3.64 & 54.33 & 76.91 \\
\hline & Flow rate $(\%)$ & 167 & 828.23 & 15.30 & 158.39 & 119.84 \\
\hline & Roe $(\%)$ & 167 & 30.61 & -25.62 & 8.01 & 6.29 \\
\hline & Net asset value per share & 167 & 11.29 & 0.67 & 3.06 & 1.53 \\
\hline & Return on net assets of main business ( $\%$ ) & 167 & 133.42 & 0.30 & 32.29 & 26.05 \\
\hline & Inventory to total assets ratio $(\%)$ & 167 & 89.64 & 0 & 15.12 & 16.24 \\
\hline & Accounts receivable account for the proportion of total assets $(\%)$ & 167 & 62.51 & 0 & 8.74 & 9.38 \\
\hline & tradable $(\%)$ & 167 & 100.00 & 13.62 & 40.38 & 11.83 \\
\hline \multirow{8}{*}{$\begin{array}{l}\text { Non-standard } \\
\text { audit opinion }\end{array}$} & Asset size & 9 & 21.81 & 18.35 & 20.43 & 1.22 \\
\hline & Asset liability ratio $(\%)$ & 9 & 196.4 & 31.49 & 72.26 & 48.32 \\
\hline & Flow rate $(\%)$ & 9 & 134.98 & 46.76 & 104.72 & 29.08 \\
\hline & Roe $(\%)$ & 9 & 33.99 & -50.37 & 0.06 & 24.68 \\
\hline & Net asset value per share & 9 & 3.13 & -0.74 & 1.30 & 1.17 \\
\hline & Inventory to total assets ratio $(\%)$ & 9 & 20.68 & 0.00 & 6.58 & 6.93 \\
\hline & Accounts receivable account for the proportion of total assets $(\%)$ & 9 & 34.09 & 0.01 & 8.00 & 10.53 \\
\hline & tradable $(\%)$ & 9 & 58.09 & 34.19 & 43.98 & 8.36 \\
\hline
\end{tabular}


Statistics that received a total of 167 companies received standard audit opinions, 9 companies received non-standard views, from the table can be seen. Received standard audit opinion of listed company's financial situation better than received non-standard audit opinion of listed companies, and non-standard audit opinion, by contrast, standard audit opinion of listed companies are on a large scale, solvency, profitability and strong, and have a good earnings management.

\subsection{Co Linear Analysis}

Co linearity refers to a linear relationship between the explanatory variables, when explain there is a significant linear correlation between variables, regression parameters influence the accuracy of, using binary logistic regression model, we must test the explanatory variables of collinearity.

Table 4. Correlation coefficient matrix. [4]

\begin{tabular}{|c|c|c|c|c|c|c|c|c|c|c|c|c|c|}
\hline & $\mathbf{X 1}$ & $\mathbf{X} 2$ & $\mathbf{X 3}$ & $\mathrm{X} 4$ & X5 & X6 & $\mathrm{X} 7$ & X8 & X9 & $\mathbf{X 1 0}$ & X11 & X12 & X13 \\
\hline $\mathrm{X} 1$ & 1.00 & 0.07 & 0.40 & 0.02 & -0.02 & 0.16 & 0.11 & 0.30 & 0.02 & -0.06 & 0.07 & 0.44 & -0.33 \\
\hline $\mathrm{X} 2$ & 0.07 & 1.00 & 0.05 & 0.01 & 0.05 & 0.00 & 0.07 & 0.12 & -0.04 & -0.06 & -0.03 & -0.19 & -0.08 \\
\hline X3 & 0.40 & 0.05 & 1.00 & -0.30 & -0.04 & 0.14 & 0.41 & 0.26 & 0.03 & -0.28 & -0.01 & 0.29 & -0.02 \\
\hline $\mathrm{X} 4$ & 0.02 & 0.01 & -0.30 & 1.00 & -0.13 & 0.04 & -0.01 & 0.00 & 0.16 & 0.27 & 0.13 & -0.05 & -0.03 \\
\hline X5 & -0.02 & 0.05 & -0.04 & -0.13 & 1.00 & -0.03 & 0.22 & -0.22 & 0.15 & 0.01 & -0.03 & 0.17 & -0.15 \\
\hline X6 & 0.16 & 0.00 & 0.14 & 0.04 & -0.03 & 1.00 & 0.16 & 0.26 & 0.02 & -0.25 & -0.22 & 0.23 & -0.08 \\
\hline $\mathrm{X} 7$ & 0.11 & 0.07 & 0.41 & -0.01 & 0.22 & 0.16 & 1.00 & 0.10 & 0.12 & -0.10 & -0.06 & -0.02 & -0.18 \\
\hline X9 & 0.02 & -0.04 & 0.03 & 0.16 & 0.15 & 0.02 & 0.12 & 0.02 & 1.00 & -0.04 & 0.14 & 0.20 & -0.02 \\
\hline $\mathrm{X} 10$ & -0.06 & -0.06 & -0.28 & 0.27 & 0.01 & -0.25 & -0.10 & 0.09 & -0.04 & 1.00 & -0.08 & -0.02 & 0.00 \\
\hline X11 & 0.07 & -0.03 & -0.01 & 0.13 & -0.03 & -0.22 & -0.06 & -0.13 & 0.14 & -0.08 & 1.00 & -0.10 & 0.08 \\
\hline $\mathrm{X} 12$ & 0.44 & -0.19 & 0.29 & -0.05 & 0.17 & 0.23 & -0.02 & 0.10 & 0.20 & -0.02 & -0.10 & 1.00 & -0.16 \\
\hline X13 & -0.03 & -0.08 & -0.02 & -0.03 & -0.15 & -0.08 & -0.18 & -0.05 & -0.02 & 0.00 & 0.08 & -0.16 & 1.00 \\
\hline
\end{tabular}

From the above data, we can see that the linear relationship between variables is not obvious, the correlation between variables will not affect the regression results, you can use two binary logistic models for analysis.

\subsection{Multivariate Analysis Results}

We know that the audit opinion translated CPA to enterprise financial statements of fair, legal and accounting processing consistency evaluation and was affected by many factors. Therefore, it is necessary to control the influence of other factors. This paper uses Logistic regression model to further analyze.

Table 5. Multivariate regression analysis results table.

\begin{tabular}{|c|c|c|c|c|c|}
\hline Step1(a) & B & S.E. & Wald & df & Sig. \\
\hline Totalfee & 0.049 & 0.021 & 5.737 & 1 & 0.607 \\
\hline Feeratio & 0.068 & 3.476 & 0.00 & 1 & 0.984 \\
\hline Lnasset & -1.110 & 0.711 & 2.437 & 1 & 0.118 \\
\hline Dta & 0.840 & 1.015 & 0.685 & 1 & 0.408 \\
\hline Currat & -0.379 & 1.163 & 0.106 & 1 & 0.745 \\
\hline Roe & -10.674 & 5.773 & 3.419 & 1 & $0.064 *$ \\
\hline Croe & -3.150 & 3.068 & 1.055 & 1 & $0.0304 * *$ \\
\hline Inventory & -6.097 & 5.555 & 1.205 & 1 & 0.272 \\
\hline Receivable & -15.999 & 10.010 & 2.555 & 1 & 0.109 \\
\hline Current & 3.931 & 3.945 & 0.993 & 1 & $0.19 * *$ \\
\hline Asize & 32.098 & 4.027 & 0.00 & 1 & $0.093^{*}$ \\
\hline Tenure & 0.172 & 0.152 & 1.285 & 1 & 0.257 \\
\hline Constant & 24.222 & 14.634 & 2.739 & 1 & 0.098 \\
\hline
\end{tabular}

* indicates a significant level of $10 \%, * *$ indicates a significant level at $5 \%$

The regression results of the model show that:

The coefficient of Feeratio is 0.068 , and its $P$ value is 0.984 , which is not obvious. The coefficient of Total fee of non-audit service and audit business is 0.049 , and its $P$ value is 0.607 , which fails to pass the test of significance. So there is no correlation between the non-audit business and the audit independence, that is, the non-audit business has no substantial impact on the audit independence, which proves the hypothesis of the article.

\section{Conclusions}

In this paper, using the provisions of the China Securities Regulatory Commission disclosed to the receiving CPA audit 
services in the A-share listed companies as the research objects from 2012 to 2014, referring related literature articles and using binary logistic regression model to analyze the independence of audit. Finally we arrive the conclusion that there is no evidence showing that accounting firms which provide non-audit services could affect the audit independence in China. This should attribute to the regulation that China promulgated the "public offering of securities company information disclosure quiz 6 -- payment accounting firm compensation and disclosure" requires listed companies in the annual report about other costs beyond the financial audit fees should be disclosed, which has certain effect in a certain extent.

Based on the above conclusions, I want to give several suggestions. Firstly, encourage and guide accounting firms to develop non-audit services and thus adapting the international development. Besides, enlarge the scope of business to increase the ability of competing. Secondly, improve the non-audit services supervision, and we could establish the supervision institute to supervise the audit and non-audit services and thus giving punishments to accounting firms and CPA which violent the independence principle. Thirdly, increase penalties. If the supervision institute find the illegal activities, they should give the CPA and accounting firms severe punishments and its punishments should far greater than the benefits [5]. Finally, improve the CPA's Professional ethics level. They are supposed to get Professional ethics training and exams, making CPA insist the independence principle all the time and maintain self-discipline in the industry.

\section{References}

[1] Liu Xing, Chen Lirong, Liu Bin, Sun Fangcheng Non-audit services affect the independence of certified public accountants? $[\mathrm{J}], \mathrm{p} 30$.

[2] Yan Yuying An empirical study on the influence of non audit services on audit independence [J], 2012(4), p13.

[3] H.s. Rosen and T. Gayer: Public Finance [M] (China Renmin University Press, 2009 (9), p235.

[4] Tang Jing An empirical study on the influence of non-audit services on audit independence [J], 2007(4), p35-45.

[5] Hao Fang The influence of non-audit services on audit independence [A], 2007 (5), p70-73.

[6] Lin Yaping Discussion on the non-audit business and audit independence based on audit perspective [J], 2012 (7), p61-p62.

[7] Li Minghui Independence of internal audit: Based on the relationship of internal audit institutions to explore the relationship between [J], 2009 (1), p69-75.

[8] Cao Yujun An empirical study on the influencing factors of audit independence [J], 2000(4), p39-51.

[9] Qi Xiaoning Shen Jiangli Analysis on the relationship between non audit services and audit independence of CPA [J], 2011(10), p57-60.

[10] Liu Jun Non-audit services and audit independence [A], 2005(9), p119-122. 